\title{
HUBUNGAN ANTARA KONSEP DIRI DENGAN CELEBRITY WORSHIP PADA REMAJA PECINTA KOREA DI MANADO DITINJAU DARI JENIS KELAMIN
}

\author{
Astrid Lingkan Mandas; Suroso; Dwi Sarwindah S \\ Fakultas Psikologi, Universitas 17 Agustus 1945 Surabaya \\ lingkanmandas@gmail.com; suroso@untag-sby.ac.id; wendy_psi@yahoo.com
}

\begin{abstract}
ABSTRAK: Tujuan penelitian ini adalah untuk melihat bagaimana hubungan antara konsep diri dengan celebrity worship dan melihat apakah ada perbedaan celebrity worship antara laki-laki dan perempuan pada remaja pecinta Korea di Manado. Penelitian ini menggunakan metode kuantitatif. Subjek penelitian ini adalah 84 remaja pecinta Korea di Manado yang tergabung dalam 4 fandom yakni EXO-L, A.R.M.Y, BLINKS, dan ONCE. Hasil analisis korelasi product moment menunjukan bahwa terdapat hubungan negatif yang sangat signifikan antara konsep diri dengan celebrity worship (rxy $=-0,771$ pada $\mathrm{p}=0,000$ ). Analisis data menggunakan uji mann-whitney menunjukkan bahwa tidak ada perbedaan celebrity worship antara laki-laki dan perempuan $(Z=-0,157$ pada $p=0,876)$
\end{abstract}

Kata kunci : celebrity worship; konsep diri

ABSTRACT: The purpose of this study is to see the correlation between self-concept and celebrity worship and to see differences in celebrity worship between male and female among Korean lovers teens in Manado. This research uses quantitative method. The subjects of this study were 84 teenage Korean lovers in Manado who joined in 4 fandom ie EXO-L, A.R.M.Y, BLINKS, and ONCE. Data analysis using product moment correlation and mann-whitney test. The result of product moment correlation analysis shows that there is a significant negative relationship between self concept and celebrity worship (rxy $=-0,771$ at $p=0,000)$. Data analysis using mann-whitney test showed that there was no difference of celebrity worship between male and female $(Z=-0.157$ at $p=$ 0,876).

Keywords : celebrity worship; self-concept

\section{Pendahuluan}

Gelombang budaya Korea telah

melanda Asia Timur selama beberapa

dekade terakhir. Tidak hanya Asia Timur,

sekarang bahkan diluar Asia. Budaya pop

Korea sering disebut sebagai Hallyu atau

Korean Wave yang mengacu pada penyebaran budaya Korea Selatan di seluruh dunia atau kecintaan terhadap eksport budaya Korea Selatan. Fenomena ini dilatarbelakangi oleh kesuksesan Korea di Piala Dunia tahun 2002. Kemenangan itu membuat prestise Korea naik di mata dunia. Korea sudah 


\section{PSIKOVIDYA}

Vol 22, No. 2, Desember 2018

mempersiapkan ini dua puluh tahun Hennida dkk, 2010). Korea dalam hal ini

sebelumnya, dimana Korea memanfaatkan globalisasi budaya sebagai

mempersiapkan komoditinya untuk ajang untuk melakukan ekspansi

menguasai pasar dunia. Selain kesuksesan kebudayaan. Hasilnya, hallyu sekarang

Korea mengungguli Jepang di Piala seolah menjadi semacam influence global

Dunia tahun 2002, tayangan drama (Pramita \& Harto, 2016). Hallyu

televisi, film dan musik yang tersebar dianggap sebagai salah satu soft power

sampai ke Jepang dan sebagian besar

Korea Selatan. Soft power adalah daya

negara-negara di Asia juga turut menjadi

tarik yang bertujuan untuk membuat bagian dari kesuksesan hallyu. Ekspor pihak lain melakukan apa yang tayangan tersebut disebutkan diinginkan. Soft power bersumber dari menggantikan ekspor budaya pop Jepang aset-aset seperti nilai politik, kebijakan (Onishi dalam Lee, 2011).

Tahun 1980 Korea berada dalam ketidakpastian karena hutang negara yang besar terutama kepada Jepang. luar negeri, dan kebudayaan dan Korea menggunakan kebudayaan sebagai soft powernya (Suryani, 2014).

Dalam konteks soft power, yang Keterpurukan Korea sebenarnya sudah berkaitan dengan merayu daripada berlangsung sejak tahun 1910 di masa memaksakan untuk mempengaruhi kolonialisme Jepang yang menjadikan perilaku, fokus pada industri sains, Korea sebagai wilayah protektorat (Seth teknologi, dan budaya ini diwujudkan dalam Hennida dkk, 2010), namun dengan dukungan kuat dari bisnis terbaik demikian pada akhir 90'an tepatnya 1997 dalam produksi dan promosi produk Korea bangkit dari keterpurukkannya hallyu seperti kpop dan kdrama (Piscarac, dengan menggunakan budaya sebagai 2016). Keberhasilan hallyu telah motor penggerak perekonomiannya yang dikenal sebagai Hallyu (Hong dalam membangun citra Korea Selatan sebagai negara yang maju dan terkesan sangat 
menarik, modis, dan dinamis (Pramita \& Harto, 2016).

Hallyu dapat terbentuk sebagai soft power karena konten budaya populer tersebut diekspor ke berbagai negara dalam bentuk produk budaya antara lain drama televisi, film, musik pop, animasi, dan games. Globalisasi budaya ini tentu saja tidak lepas dari peran teknologi dalam pertukaran informasi antar budaya.

Salah satu kunci sukses keberhasilan k-pop berasal dari penggunaan cultural technology atau teknologi budaya, sebuah konsep yang dipopulerkan oleh Lee Soo Man selaku pendiri SM Entertainment.

Hal yang penting dari sebuah ekspansi budaya adalah kemasan. Suatu negara tidak bisa menjajahkan budayanya tanpa adanya kemasan yang menarik layaknya Hallyu. Faktor lain yang menunjang popularitas kebudayaan Korea di dunia adalah karena pemerintah Korea memberikan dukungan yang besar dalam hal ini. Pemerintah Korea Selatan secara masif membantu penyebaran Hallyu dengan menggunakan saluran televisi internasional seperti Arirang. Hallyu

dijadikan proyek nasional oleh pemerintah Korea sebagai bentuk dari soft power (Jae dkk, 2017). Pemerintah Korea Selatan menjalin kerja sama dengan industri musik terbesar di Korea Selatan seperti SM Entertainment, JYP Entertainment, dan YG Entertainment untuk memaksimalkan efek sinergis yang mengkhususkan diri dalam penyebaran hallyu sebagai upaya memperkenalkan, mempromosikan, dan menyebarluaskan budaya Korea di dunia International (Suryani,2015).

Awal mula kesuksesan hallyu di Asia adalah dengan populernya drama Korea berjudul Endless Love pada tahun 2000. Kesuksesan drama ini kemudian menjadi pintu sukses bagi drama yang lain seperti All About Eve, Winter Sonata, Full House, Friends, Hoteliar dan Glass Shoe (Jae dkk, 2017), kemudian setelah itu muncullah drama-drama lain seperti Boys Before Flowers pada tahun 2009. Mulai tahun 2003, k-pop menambah kepopuleran hallyu melalui kehadiran 


\section{PSIKOVIDYA}

Vol 22, No. 2, Desember 2018

boyband seperti TVXQ, Super Junior, Bigbang, Shinee dan Girlband seperti SNSD (Girls Generation), Wondergirls, Miss A dll. Tahun 2012, sejak lagu 'Gangnam Style" oleh Psy menduduki peringkat tertinggi di papan musik Billboard dan video paling sering ditonton di Youtube membuat mata dunia semakin tertuju pada Korea Selatan (https://id.wikipedia.org/wiki/Hallyu

diakses pada 18 Juni 2017).

Melalui Hallyu, Korea Selatan gencar-gencarnya menetaskan aktris, aktor, penyanyi melalui industri hiburan yang sudah sangat dikenal sejak 10 tahun terakhir ini tidak hanya di negara-negara Asia saja tapi di luar Asia seperti Amerika dan Afrika. Produk kebudayaan yang berupa k-pop (musik pop), k-drama (drama Korea) dan variety show memang memberi dampak yang besar di berbagai aspek kehidupan di seluruh dunia tida terkecuali di Indonesia. Di Indonesia kesuksesan hallyu memberi dampak pada peningkatan minat masyarakat untuk mempelajari bahasa Korea, minat masyarakat terhadap produk-produk Korea seperti fashion dan kosmetik dan makanan, minat untuk studi mengenai Korea, termasuk minat untuk melakukan perjalanan ke Korea Selatan (Pramita \& Harto, 2016), dan masyarakat yang paling terdampak adalah remaja tidak terkecuali remaja di Indonesia.

Kemasan budaya yang menarik berupa k-pop, k-drama dan variety show memang memberi dampak yang besar terhadap remaja di Indonesia khususnya konsep diri. Pengaruh tersebut dapat terlihat dari penampilan, bahasa, bahkan perilaku dari para remaja di Indonesia. Melalui tiga hal tersebut dapat terlihat bagaimana Korea Selatan memainkan soft powernya.

Melihat dari segi penampilan, banyak dari remaja yang berpakaian ala korea. Meskipun tidak sepenuhnya meniru cara berpakaian korea tapi paling tidak ada satu unsur dari cara berpakaian korea yang melekat pada cara remaja berpakaian misalnya make-up, model rambut, dan pakaian yang dipakai. Semua 


\section{PSIKOVIDYA}

Vol 22, No. 2, Desember 2018

itu diperoleh baik dari boyband, girlband, maupun k-drama yang menjadi favorit remaja. Tidak bisa dipungkiri bahwa dibalik setiap tayangan baik drama maupun musik, industri hiburan dari

Korea kerap menyisipkan unsur-unsur budaya berpakaian yang sedang trend di Korea misalnya kosmetik sampai pada pakaian.

Beberapa jurnalis berpendapat bahwa ekspor drama televisi, film, dan musik Korea Selatan berpengaruh terhadap promosi produk budaya lainnya seperti makanan, bahasa, industri pariwisata di Korea Selatan dan juga fashion (Suryani, 2015; KCIS, 2011). Misalnya penampilan 'no make-up look' yaitu jenis make-up tipis dan natural ini menjadi trending make up setelah kebanyakan drama Korea menyuguhkan penampilan aktris dan aktornya dengan tampilan natural. Selain itu pakaian seperti school blazer sempat menjadi trending fashion semenjak drama Boys Before Flower menjadi tayangan favorit di Indonesia waktu itu. Korea Selatan mengemas unsur tersebut dengan sangat baik sehingga itulah yang kemudian diserap oleh siapapun yang melihatnya termasuk remaja di Indonesia. Hal ini disebabkan oleh apa yang dianggap oleh remaja dalam tayangan Korea tersebut menarik dan cocok bagi remaja. Terlebih lagi apabila remaja mendapat respon positif dari lingkungan sekitar. Salah seorang testimoni yang termasuk dalam fandom (fans domain) atau fansclub E.L.F (sebutan untuk fans Super Junior) mengakui bahwa setelah mengubah penampilannya dengan menggunakan kostum ala Korea, teman-temannya memberi komentar positif.

Beberapa tahun terakhir, Korea Selatan telah menjadi salah satu kiblat fashion Asia. Beragam gaya busana ala Korea Selatan, khususnya street style, kerap menjadi inspirasi remaja di negara Asia lain, termasuk Indonesia. Menanggapi fenomena tersebut, Lie Sang-Bong, desainer asal Korea Selatan menjawab secara diplomatis "Fashion memiliki tempat sebagai tren itu sendiri. 


\section{PSIKOVIDYA}

Vol 22, No. 2, Desember 2018

Sekarang tidak hanya di Seoul, di Asia pun fashion Korea sangat dikenal." Lie Sang-Bong menilai kepopuleran fashion Korea Selatan ke belahan dunia lain tidak lepas dari fenomena Hallyu. "Konten budaya Korea sendiri, seperti drama dan film, sangat bisa dibilang mendunia". Katanya (https:// cantik. tempo .co /read /815206/hallyu-wave-kunci-popularitas-fa shion-korea-selatan diakses pada 18 Juni 2017).

Tidak hanya dari segi penampilan saja, dari cara berbicara juga berbeda dari sebelum dan sesudah terkena dampak Hallyu. Dalam kehidupan sehari-hari, kita akan tahu mana diantara remaja yang sudah terkena dampak Hallyu. Hal tersebut nampak dari 'jargon' atau istilah dalam bahasa Korea yang disisipkan dalam pembicaraan seperti 'aigoo, omo, hwaiting, daebak, heol' yang tentu saja hanya dipahami oleh remaja sesama pecinta Korea. Apabila individu adalah seorang die-hard (fans fanatik) baik k-drama maupun k-pop, individu tidak hanya menyisipkan sekedar istilah saja tapi benar-benar berbicara seperti orang Korea. Hal tersebut dipelajari melalui drama dan musik. Apalagi musik k-pop terkenal easy-listening dan enak untuk ditiru. Tidak sedikit remaja yang rela mengambil kursus bahasa Korea, hanya untuk bisa berbahasa Korea. Seorang responden yang tergabung dalam komunitas budaya Korea dari suatu universitas di Surabaya mengatakan “awalnya saya menyukai korea karena k-pop. Lalu saya berpikir mungkin akan keren kalau saya bisa berbicara dengan bahasa Korea seperti para oppa yang ganteng itu. Akhirnya saya ikut kursus bahasa Korea di kampus ini. Ternyata bahasanya tidak terlalu sulit untuk dipelajari. Justru lebih sulit bahasa Jepang menurut saya."

Selain cara berpenampilan dan berbahasa, peran Hallyu juga terlihat dari perilaku remaja di Indonesia. Hal yang unik ditemukan dari individu yang bergabung dengan salah satu fandom dalam hal ini fandom k-pop. Ciri khas suatu boyband dan girlband yang paling 
menyolok adalah ketampanan dan kecantikan dari masing- masing personil dan hal itu kerap membuat para fansnya seperti kehilangan akal sehat apalagi ketika para fans melihat idolnya secara langsung di depan mata seperti pada saat sedang konser. Perilaku yang muncul ketika individu terlalu mengidolakan salah satu personil adalah individu menganggap personil tersebut sebagai suami/istrin yang hanya miliknya seorang sehingga apabila ada antifan atau haters yang mengkritik atau bahkan menghina idolnya, individu tersebut akan melontarkan hinaan dan kritikan untuk membalas haters/fandom yang mengkritik idolnya. Hal ini disebut sebagai Fan War atau perang fans.

Kehadiran Hallyu di tanah air memang seperti demam yang menyerang kaum remaja. Sebelum Korea Selatan menjajahkan budayanya, budaya Barat sebe- narnya sudah telebih dahulu masuk ke Indonesia dan sempat bertahan untuk beberapa saat. Budaya dari Barat memang cukup memberikan pengaruh besar terhadap Indonesia akan tetapi unsur terlalu bebas yang terkandung dalam budaya tersebut cenderung menimbulkan kontroversi di Indonesia sehingga semua unsur budaya Barat tidak bisa diterima di Indonesia. Berbeda dengan Hallyu, budaya ini sangat cepat melekat di hati masyarakat Indonesia dalam hal ini remaja karena ada banyak nilai-nilai kebudayaan yang hampir sama dengan nilai kebudayaan yang ada di Indonesia, misalnya menghormati orang yang lebih tua dan cara berpakaian.

Berkaca dari karakteristik masa remaja, maka pemaparan di atas sesuai dengan diri remaja. Salah satu ciri masa remaja sebagai masa dimana individu mengembangkan diri melalui proses interaksi dengan lingkungan dimana individu menganggap orang / hal lain sebagai bagian dari dirinya yang bertujuan untuk membentuk 'ego ideal' berupa cita-cita, termasuk idola yang menggambarkan wujud ego di masa depan. Masa remaja sebagai masa mencari identitas. Remaja mulai sibuk 


\section{PSIKOVIDYA}

dengan problem 'siapa saya' (Erickson

dalam Santrock, 2007). Masa remaja juga

adalah masa dimana individu cenderung

tidak realistik dimana individu

memandang dirinya sebagai apa yang

diinginkan, bukan sebagaimana adanya,

artinya remaja memiliki idealisme yang

cukup berlebihan terkait dirinya.

Semakin remaja mengenal hallyu

membuat remaja semakin menjadikan

k-pop sebagai panutan seha- ri-hari. Hal

ini tentu saja berdampak pada remaja

yang akan semakin menjauh dari budaya

aslinya dan bahkan tidak begitu tertarik

dengan budaya lokalnya. Kemasan

budaya yang menarik dalam bentuk

K-Drama dan K-Pop mengontaminasi

budaya yang ada di Indonesia, dan

masyarakat yang paling terdampak adalah

remaja yang memang pada dasarnya

adalah usia dimana individu sedang

mencari identitas sehing- ga remaja

mengalami yang dinamakan dengan krisis

identitas. Salah satu ciri dari identitas diri

adalah individu tersebut memiliki konsep

diri.
Calhoun dan Acocella (1990)

mengemukakan bahwa konsep diri adalah

bagaimana individu melihat dirinya yang

terdiri dari pengetahuan, pengharapan, dan penilaian terhadap dirinya sendiri.

Konsep diri dipengaruhi oleh

faktor-faktor seperti orangtua, teman

sebaya, dan masyarakat. Yang artinya

penilaian terhadap diri individu tidak

semata-mata terjadi karena persepsi

individu sendiri melainkan juga sebagai

hasil dari interaksi dengan orang lain

dimana penilaian orang lain berpengaruh

pada pembentukan konsep diri individu.

Remaja yang dikatakan memiliki

konsep diri positif adalah ketika

kehadiran idola pop Korea tidak membuat individu menjadi sama persis dengan idolanya. Apabila melihat dari teori belajar model yang diperkenalkan Bandura tentang proses yang terjadi dalam modelling, dapat dilihat mana remaja yang memiliki konsep diri yang positif dan mana yang negatif. Berdasarkan teori belajar sosial Bandura (1997) melalui perilaku modelling 


\section{PSIKOVIDYA}

terdapat beberapa proses yakni perhatian

(attention), pengendapan (retention), reproduksi motorik (reproduction), dan penguatan (motivation).

Perhatian (attention) yaitu ketika idol hallyu hadir sebagai model, individu akan memfokuskan perhatiannya pada setiap aspek dalam diri idol mulai dari cara berpakaian, cara berbicara, cara berperilaku. Kedua yaitu pengendapan (retention), apa yang diamati oleh individu dari idol hallyu masuk ke dalam memori individu. Ketiga reproduksi motorik (reproduction), yaitu kemampuan individu untuk merealisasikan aspek-aspek idol hallyu yang masuk ke dalam memori individu untuk dimanifestasikan dalam perilaku. Dalam proses ini dapat terlihat mana individu yang memiliki konsep diri yang positif dan mana yang negatif. Perilaku yang dipelajari oleh individu melalui model idolanya selanjutnya akan direalisasikan dalam bentuk tindakan baru. Pada saat memunculkan tindakan tersebut individu tentu harus berlatih, yang artinya perilaku tersebut akan diulang-ulang sambil individu membandingkan dirinya dengan perilaku model dalam memorinya. Pada tahap ini terjadi proses berpikir oleh individu tentang apakah perilaku yang dimunculkan tersebut cocok atau tidak dengan dirinya. Individu dengan konsep diri yang positif tentu saja akan mempertimbangkan apakah perilaku itu pantas dan sesuai tidak hanya untuk dirinya tapi juga untuk lingkungannya. Individu dengan konsep diri yang negatif tidak melakukan filter tersebut dan menerima setiap aspek dalam diri idola secara mentah, misalnya cara berpakaian idol, cara berbicara maupun cara berperilaku. Keempat penguatan (motivation) yaitu seberapa baik kemampuan individu memodel perilaku idola. Penguatan menjadi relevan ketika ada timbal balik yang baik dari lingkungan tentang perilaku yang benar. Individu dengan konsep diri yang positif melibatkan pendapat dari lingkungan sebagai bentuk evaluasi karena individu sadar bahwa konsep diri yang baik adalah 


\section{PSIKOVIDYA}

Vol 22, No. 2, Desember 2018

terbentuk atas dua penilaian yakni

penilaian terhadap diri sendiri dan

penilaian lingkungan terhadap dirinya,

sedangkan individu yang memiliki konsep

diri yang negatif hanya melihat satu sudut

pandang yakni dari dirinya sendiri dan

mengabaikan penilaian dari lingkungan.

Bandura (1997), menjelaskan

bahwa modeling merupakan suatu peru-

bahan pada diri individu terhadap tingkah

laku atau perilaku model yang ditiru,

kebanyakan tingkah laku seseorang

terjadi karena pengamatan atau belajar

model. Model yang ditiru bukan hanya

orang-orang yang konkrit ada, melainkan

juga model-model yang simbolis yang

dilihat pada televisi atau dibaca dalam

buku. Rahmaningsih \& Martani (2014)

dalam penelitiannya menemukan bahwa

pengamatan terhadap tokoh-tokoh

menghasilkan gambaran yang berperan

terhadap dinamika konsep diri remaja

melalui mekanisme perbandingan sosial

dan modeling.

Konsep diri dipengaruhi oleh beberapa faktor, salah satunya adalah significant others atau orang-orang yang

dianggap penting (Rice \& Dolgin dalam

Rahmaningsih \& Martani, 2014). Seiring

dengan berkembangnya media massa dan budaya populer membuat tokoh-tokoh dalam media massa menjadi salah satu orang yang dianggap penting oleh remaja saat ini (Giles \& Maltby dalam Rahmaningsih \& Martani, 2014).

Media massa menghadirkan figur suatu idola yang memberikan dampak pada persepsi remaja terhadap dirinya sehingga remaja secara aktif dan kreatif mengidentifikasi simbol-simbol kultural guna membentuk konsep dirinya (Jannah, 2014). Dalam sebuah penelitian yang lain yang dilakukan oleh Kurniati, dkk (2015) menemukan bahwa dampak budaya Korea terhadap remaja adalah identitas diri yang rendah. Remaja yang terkena dampak budaya pop Korea meniru unsur-unsur budaya dari tayangan televisi, drama, dan lagu yang bernuansa Korea dan hal itu nampak dari cara remaja berpenampilan.

Perilaku modeling terjadi ketika 


\section{PSIKOVIDYA}

ada sosok idola yang diidolakan oleh individu dalam hal ini aktris dan aktor dari Korea yang lahir melalui hallyu. Remaja fans hallyu adalah mereka yang terobsesi dengan selebriti, artis, film, program televisi, band, dan lain-lain. Remaja pecinta budaya Korea akan mampu untuk meng- hapal lirik lagu artis kesayangan dan kalimat dalam sebuah film favorit (Hills dalam Sari, 2013) atau memakai atribut yang berkaitan dengan artis kesayangannya, rela mengantri tiket konser sang artis, serta mengetahui setiap detail kehidupan pribadi dan pekerjaan artis (Lewis dalam Sari, 2013). Obsesi remaja fans hallyu ini disebut sebagai Celebrity Worship.

Menurut Maltby (dalam Widjaja dan Ali, 2015), Celebrity worship adalah sebuah bentuk identitas yang terdapat di dalam diri individu yang membantu proses pemaknaan dan identifikasi terhadap selebriti idola sebagai upaya untuk mengembangkan sebuah identitas diri dan rasa pemenuhan dalam individu tersebut.
Tiga aspek dalam celebrity worship adalah entertainment - social, intense personal, dan borderline - pathological. Menurut Raviv (dalam Darfiyanti \& Putra, 2012) pemujaan merupakan bentuk kekaguman dengan intensitas yang tidak biasa dan penghormatan terhadap idola. Bentuk kekaguman tersebut membentuk perilaku memuja selebriti tertentu yang disebut celebrity worship. McCutcheon berspekulasi bahwa sifat yang dimiliki oleh celebrity worshipper (fans) mirip dengan sifat kecanduan. Makin tinggi tingkat kecanduan terhadap sosok selebriti, maka semakin tinggi tingkat pemujaan seseorang dan berpengaruh pada semakin tinggi pula tingkat keterlibatannya dengan sosok idola (celebrity involvement) (Widjaja \& Ali, 2015).

Apabila dilihat dari jenis kelamin, perempuan lebih meminati budaya Korea dibanding laki-laki. Hasil penelitian dari Syam (2015) menunjukan bahwa $74 \%$ remaja perempuan menaruh minat yang tinggi terhadap budaya Korea sedangkan 


\section{PSIKOVIDYA}

Vol 22, No. 2, Desember 2018

laki-laki $13 \%$. Syam menjelaskan bahwa

keadaan demikian disebabkan karena

siaran Korea lebih menyentuh pada unsur perempuan secara umum. Banyak film ataupun drama Korea menyentuh pada

cinta, kasih sayang dan kesedihan dimana sifat-sifat tersebut banyak dimiliki oleh perempuan daripada laki-laki.

Berdasarkan pemaparan masalah di atas maka yang menjadi dasar peneliti mengangkat judul ini adalah ketika hallyu hadir dengan kemasan budaya yang menarik, membuat remaja terobsesi dengan aktris, aktor, ataupun idol k-pop sehingga menimbulkan kekaguman yang tidak biasa. Kekaguman ini mengarah kepada keterlibatan remaja dengan sosok idola kesayangan atau disebut celebrity involvement. Masa remaja yang pada dasarnya adalah masa pengembangan diri dimana orang / hal lain dianggap sebagai bagian dari dirinya sendiri, masa mencari identitas, dan masa yang tidak realistik membuat sosok selebriti sebagai significant others yang berperan penting dalam dirinya. Remaja melalukan perilaku modelling yaitu dengan mencari informasi dengan idola baik itu lagu, atribut dan detail kehidupan pribadi dari sang idola, setelah itu remaja mengolah informasi yang didapatkan, mengidentifikasi unsur-unsur idola tersebut dengan dirinya, melihat mana yang cocok dengan dirinya kemudian menggunakan identifikasi itu untuk membentuk ego idealnya. Hal ini menunjukan bahwa remaja memiliki konsep diri yang negatif. Dampak dari konsep diri yang negatif adalah kecenderungan remaja untuk melakukan celebrity worship.

Tujuan dalam penelitian ini adalah hendak menjawab hipotesis yang pertama ada hubungan antara konsep diri dengan celebrity worship. Hipotesis yang kedua yaitu ada perbedaan celebrity worship antara laki-laki dan perempuan.

\section{Celebrity Worship}

Maltby \& Liza (dalam Sunarni, 2015), mengatakan bahwa "celebrity worship is a parasocial relationship (one 


\section{PSIKOVIDYA}

Vol 22, No. 2, Desember 2018

side relationship in which an individual

know the other, but the other does not."

atau hubungan para sosial atau hubungan

satu sisi, dimana individu mengenal yang

lain, tetapi yang lain tidak. Celebrity

worship adalah identitas struktur yang

terdapat di dalam diri individu yang

membantu penyerapan psikologis

terhadap selebriti idola dalam upaya

untuk membangun identitas diri individu

tersebut.

Celebrity worship adalah perilaku

obsesi individu untuk terlalu terlibat di

setiap kehidupan selebriti, sehingga

terbawa dalam kehidupan sehari-hari

individu tersebut. Celebrity worship

dipengaruhi oleh kebiasaan seperti

melihat, mendengar, membaca dan

mempelajari tentang kehidupan selebriti

secara berle- bihan hingga menimbulkan

sifat empati, identifikasi, obsesi, dan

asosiasi yang menimbulkan konformitas

(Maltby dkk dalam Kusuma, 2014;

Widjaja \& Ali, 2015).

Remaja yang sedang dalam proses pencarian jati diri akan senantiasa mencari sebuah contoh yang mereka

anggap menarik dan mempunyai

nilai-nilai ideal bagi remaja (Santrock

dalam Sunarni, 2015) memaparkan bahwa

ketika remaja mengeksplorasi dan

mencari identitas budayanya, remaja

seringkali bereksperimen dengan

peran-peran yang berbeda. Selebriti

merupakan salah satu dari berbagai model

yang dijadikan remaja contoh untuk

bereskperimen dengan peran

berbeda-beda.

Celebrity worship biasanya melibatkan satu atau lebih selebriti yang sangat disukai oleh individu seakan-akan tidak bisa terlepas dari hal-hal yang berhubungan dengan selebriti tersebut.

Celebrity worship adalah perilaku obsesif individu untuk terlalu terlibat dalam kehidupan idola selebrity atau sebuah kekaguman yang tidak biasa yang menimbulkan ke- canduan sehingga terjadi penyerapan psikologis terhadap selebriti idola melalui aktivitas melihat, mendengar, membaca dan mempelajari kehidupan selebriti secara berlebihan. 
Menurut Maltby, dkk (dalam

Widjaja \& Ali), celebrity worship dibagi menjadi tiga aspek yaitu entertainment -social, intense-personal, dan borderlinepathological.

Entertainment - Social merupakan aspek yang digambarkan dengan motivasi yang mendasari pencarian aktif fans terhadap celebrity. Keterlibatan fans dengan celebrity idola yang bertujuan untuk hiburan atau menghabiskan waktu, yang didasari oleh ketertarikan fans terhadap bakat, sikap, perilaku, dan hal yang dilakukan oleh celebrity tersebut. Biasanya kegiatan pencarian aktif fans dilakukan dengan penggunaan media sebagai sarana untuk men- cari informasi mengenai celebrity idola. Pada aspek ini, fans juga merasa bahwa penting atau senang membicarakan celebrity idolanya dengan orang banyak dan juga senang membicarakan fans lain yang juga mengidolakan celebrity yang sama.

Intense-personal merupakan aspek yang menggambarkan perasaan yang intensif dan kompulsif terhadap celebrity dan hampir mendekati perasaan obsesif fans terhadap celebrity idolanya. Fans memiliki kebutuhan untuk mengetahui apapun tentang celebrity idolanya, mulai dari berita terbaru hingga informasi mengenai pribadi celebrity. Rasa empati yang tinggi yang dirasakan fans terhadap idolanya membuat fans merasa memiliki ikatan khusus dengan celebrity idolanya bahkan ikut merasakan apa yang terjadi dengan celebrity tersebut.

Borderline - pathological merupakan tingkatan paling tinggi atau mendalam dari hubungan keterlibatan fans dengan celebrity. Hal ini digambarkan dalam sikap seperti kesediaan untuk melakukan apa pun demi celebrity tersebut meskipun apa yang dilakukan melanggar hukum; fans mulai berfantasi dan berkhayal memiliki kedekatan khusus dengan celebrity idolanya; fans memiliki keyakinan idolanya akan menolong saat fans tersebut mem- butuhkan bantuan. Fans yang seperti ini tampak memiliki pemikiran yang tidak terkontrol dan 


\section{PSIKOVIDYA}

Vol 22, No. 2, Desember 2018

menjadi irasional.

Terdapat tiga faktor yang

mempengaruhi celebrity worship

(McCutcheon dkk dalam Kusuma, 2014) yaitu :

Usia. Celebrity worship mencapai puncaknya pada usia remaja, dan menurun perlahan pada usia dewasa.

Ketrampilan sosial. Individu dengan ketrampilan sosial yang buruk meng- anggap celebrity worship sebagai kompensi atas tidak terjadinya hubungan sosial yang nyata.

Jenis kelamin. Laki-laki lebih cenderung mengidolakan selebriti perempuan, sedangkan perempuan cenderung memilih selebriti laki-laki sebagai idolanya.

\section{Konsep Diri}

Konsep diri merupakan suatu konstruk yang mempengaruhi setiap aspek dari pengalaman hidup manusia seperti cara berpikir, emosi, persepsi dan perilaku individu. Cara pandang indi- vidu terhadap dirinya akan membentuk suatu konsep dirinya sendiri. Konsep tentang diri merupakan hal-hal yang penting bagi kehidupan individu karena konsep diri menentukan bagaimana individu bertindak dalam berbagai situasi (Calhoun dan Acocella, 1990).

Pengharapan mengenai diri akan menentukan bagaimana individu akan bertindak dalam hidup. Hal ini karena konsep diri merupakan bagian diri yang mempengaruhi setiap aspek pengalaman baik itu pikiran, perasaan, persepsi, maupun tingkah laku individu (Calhoun dan Acocella, 1990). Sama seperti yang dikatakan oleh Mead (dalam Burns, 1993) bahwa konsep diri merupakan pandangan, penilaian, dan perasaan individu mengenai dirinya yang timbul sebagai hasil dari suatu interaksi sosial. Artinya, konsep diri adalah pandangan individu tentang dirinya yang berisi tentang pengetahuan tentang diri, pengharapan individu, dan penilaian individu mengenai dirinya yang timbul akibat suatu interaksi sosial yang berpengaruh pada 


\section{PSIKOVIDYA}

setiap tindakan dalam hidupnya.

Stuart (dalam Syam'ani, 2011) mendefinisikan konsep diri sebagai semua pikiran, keyakinan dan kepercayaan yang membuat seseorang mengetahui tentang dirinya dan mempengaruhi hubungannya dengan orang lain. Hal tersebut serupa dengan yang dikemukakan oleh Potter dan Perry (dalam Syam'ani, 2011) yang mengemukakan bahwa konsep diri adalah pandangan individu terhadap di- rinya sendiri yang merupakan kombinasi dari pikiran, sikap dan persepsi yang disadari atau tidak. Singkatnya, konsep diri adalah pandangan semua pikiran, si- kap dan persepsi, keyakinan dan kepercayaan yang disadari atau tidak yang membuat individu mengetahui tentang dirinya dan mempengaruhi hubungannya dengan orang lain.

$$
\text { Konsep diri adalah gambaran }
$$
individu secara utuh tentang dirinya yang berisi tentang pengetahuan, penilaian, harapan dan keyakinan tentang dirinya dari berbagai aspek dalam hidupnya seperti fisik, psikologis, emosi, dan sosial dari individu yang diperoleh melalui pengalaman interaksi dengan orang lain yang berpengaruh pada cara individu bertindak dalam kehidupannya.

Menurut Calhoun \& Acocella (1990) terdapat tiga dimensi konsep diri yaitu pengetahuan diri (knowledge), harapan diri (expectation), penilaian diri (evaluation).

Pengetahuan diri (knowledge) yaitu pngetahuan sesesorang tentang dirinya sendiri, yakni sejumlah label yang melekat pada diri seseorang yang menggambarkan orang tersebut. Remaja yang tergabung dengan fandom hallyu akhirnya akan menambah luas pengetahuan tentang daftar julukan dari dirinya misalnya 'saya exo-L, saya hallyu dan sebagainya. Pengetahuan ini kemudian akan dimasukkan ke dalam diri mentalnya dan akan terjadi proses perbandingan kualitas diri disini.

Harapan diri (expectation) yaitu harapan diri mengacu pada ideal self, yaitu harapan terhadap diri sendiri tentang 
bagaimana diri seharusnya yang

diidealkan. Mengenal hallyu dan tergabung dalam fandom membuat individu ingin menjadi seperti artis idolanya melalui proses identifikasi.

Penilaian diri (evaluation) yaitu penilaian yang dilakukan setiap individu terhadap dirinya sendiri setiap hari akan diukur dengan mengajukan pertanyaan apakah diri bertentangan dengan (a) 'saya dapat menjadi', yakni pengharapan bagi diri individu itu sendiri dan (b) 'saya seharusnya menjadi apa' yaitu standar individu bagi dirinya sendiri. Hasil pengukuran dari dua pertanyaan ini disebut sebagai rasa. Ketika idol celebrity hallyu hadir sebagai standar pengukuran diri bagi individu yang dapat menjadi pengharapan dirinya akan berpengaruh terhadap standar indi- vidu bagi dirinya sendiri. Dalam penelitian ini alat ukur yang digunakan untuk mengukur konsep diri mengacu pada konsep diatas.

Ketika individu lahir, individu tidak memiliki pengetahuan tentang dirinya, tidak memiliki penilaian terhadap diri sendiri, namun seiring dengan berjalannya waktu individu mulai bisa membedakan antara dirinya, orang lain dan benda-benda di sekitarnya, dan pada akhirnya individu mulai mengetahui siapa dirinya, apa yang diinginkan serta dapat melakukan penilaian terhadap dirinya sendiri (Calhoun dan Acocella, 1990).

Faktor yang mempengaruhi konsep diri menurut Calhoun dan Acocella (1990) yaitu :

Orangtua. Orangtua adalah kontak sosial yang paling awal dan paling kuat. Apa yang dikomunikasikan oleh orangtua pada anak lebih menancap dari- pada informasi lain yang diterima sepanjang hidupnya. Orangtua me- ngajarkan bagaimana menilai diri sendiri dan orangtua yang lebih banyak membentuk kerangka dasar untuk konsep diri.

Teman Sebaya. Penerimaan anak dari kelompok teman sebaya sangat dibutuhkan setelah mendapat cinta dari orang lain dalam mempengaruhi konsep diri. Jika penerimaan ini tidak datang, dibentak atau dijauhi maka konsep diri 


\section{PSIKOVIDYA}

Vol 22, No. 2, Desember 2018

akan terganggu. Selain masalah

penerimaan atau penolakan, peran yang

diukur anak dalam kelompok teman

sebaya sangat mempunyai pengaruh yang

dalam pada pandangannya tentang dirinya

sendiri.

Masyarakat. Individu tidak terlalu

mementingkan kelahiran mereka, tetapi

masyarakat menganggap penting

fakta-fakta yang ada pada seorang anak,

seperti siapa bapaknya, ras, dan lain-lain.

Akhirnya penilaian ini sampai kepada

anak dan masuk ke dalam konsep diri.

Masyarakat memberikan harapan-harapan

kepada anak dan melaksanakan harapan

tersebut. Jadi dalam pembentukan konsep

diri orangtua, teman sebaya, dan

masyarakat memiliki peranan yang sangat

penting dalam memberitahu individu

bagaimana mengidentifikasi diri.

\section{Modelling}

Teori belajar modelling merupakan

teori yang dikemukakan oleh Albert

Bandura, dimana modelling adalah proses belajar dengan mengamati tingkah laku atau perilaku dari orang lain di sekitar kita. Modelling yang artinya meniru, dengan kata lain juga merupakan proses pembelajaran dengan melihat dan memperhatikan perilaku dari oang lain kemudian mencontohnya. Hasil dari modelling atau peniruan tersebut cenderung menyerupai bahkan sama perila- kunya dengan perilaku orang yang ditiru tersebut (Bandura, 1967).

Modelling dalam belajar merupakan dasar percepatan belajar juga merupakan suatu konsep bagi proses memproduksi atau membentuk perilaku yang dipelajari melalui mengobservasi orang lain. Prinsip dari modelling sederhana yaitu 'memamerkan' perilaku seseorang. Prosedur ini memanfaatkan proses belajar melalui pengamatan, dimana perilaku seseorang atau beberapa orang model atau teladan berperan sebagai perangsang terhadap pikiran, sikap, atau perilaku pengamat.

Kemampuan mengamati merupakan penekanan pada modelling. 


\section{PSIKOVIDYA}

Melalui pengamatan yang dilakukan, 2004)

individu tidak perlu belajar secara trial

and error. Hasil pengamatan tersebut akan

disimpan dalam bentuk simbol yang akan

digunakan pada saat yang diperlukan.

Bandura percaya bahwa individu bisa

mengembangkan perilaku dengan

pola-pola baru dalam berbagai situasi

tanpa penguatan eksternal, melainkan

cukup dengan kehadiran model yang bisa

diamati atau dicontoh pada saat itu.

Walaupun demikian, fungsi dari

pemerkuat eksternal. Walaupun demikian

fungsi dari pemerkuat eksternal tidak

diabaikan, pemerkuat eksternal ini

berfungsi sebagai informasi (memberikan

gambaran mengenai efek-efek dari

perilaku terhadap lingkungan) (Ibid dalam

Falah, 2004).

Bandura juga percaya bahwa emosi dapat dipelajari secara vicarious, misalnya dapat belajar emosi melalui televisi. Peran yang dimainkan oleh pemain sinetron atau film di televisi dapat menggugah emosi kita untuk melakukan modelling yang sama (Ibid dalam Falah,

\section{Metodologi}

enelitian dilaksanakan pada tanggal 28 s.d. 29 Mei 2018. Penelitian ini menggunakan metode kuantitatif. Subjek dalam penelitian ini yaitu remaja pecinta Korea di Manado yang tergabung dalam empat fandom besar yakni EXO-L, ARMY, BLINKS, dan ONCE sebanyak 84 orang yang diperoleh dengan menggunakan teknik cluster random sampling.

Metode pengumpulan data dilakukan dengan memberikan skala CAS (celebrity attitude scale) untuk mengukur celebrity worship yang disusun oleh Maltby dkk (2006) yang kemudian dimodifikasi oleh peneliti dengan menambahkan atau mengganti dengan alasan karena ada beberapa item yang kurang sesuai dengan keadaan di Indonesia. Aspek yang diukur dalam CAS adalah entertainment - social, intense personal, dan borderline - pathological. Konsep diri diukur melalui tiga dimensi 


\section{PSIKOVIDYA}

Vol 22, No. 2, Desember 2018

konsep diri yakni pengetahuan diri, harapan diri, dan penilaian diri dengan menggunakan skala yang dibuat oleh peneliti.

Metode analisis data yang pertama menggunakan teknik korelasi product moment untuk menguji hipotesis pertama yaitu ada hubungan antara konsep diri dengan celebrity worship. Metode analisis data yang kedua menggunakan uji mann-whitney untuk melihat perbedaan celebrity worship antara laki-laki dan perempuan.

\section{Hasil dan Pembahasan}

Hipotesis pertama adalah ada hubungan negatif antara konsep diri dengan celebrity worship. Setelah dilakukan uji statistik korelasi product moment dengan menggunakan program SPSS versi 20.0 diperoleh koefisien korelasi $(\mathrm{rxy})=-0,771$ dengan taraf signifikansi $\mathrm{p}=0,000(\mathrm{p}<0,01)$ yang berarti ada hubungan negatif yang sangat signifikan antara konsep diri dengan celebrity worship.
Hipotesis kedua dalam penelitian ini adalah ada perbedaan celebrity worship antara laki-laki dan perempuan. Hasil uji mann-whitney diperoleh nilai koefisien $\mathrm{Z}$ sebesar $-0,157$ dan taraf signifikansi sebesar $0,876(\mathrm{p}>0,05)$ yang berarti tidak terdapat perbedaan celebrity worship antara laki-laki dan perempuan.

Hal lain yang ditemukan dalam penelitian ini antara lain yang pertama hasil analisis untuk menguji hubungan antara konsep diri dengan entertainment social yang dilakukan dengan uji statistik korelasi product moment diperoleh koefisien korelasi (rxy) $=-0,779$ dengan taraf signifikansi $\mathrm{p}=0,000(\mathrm{p}<0,01)$ yang berarti ada hubungan negatif yang sangat signifikan antara konsep diri dengan entertainment - social. Apabila melihat dari uji regresi sederhana, sumbangan efektif konsep diri terhadap entertainment-social sebesar $0,446 \quad(r$ square). Hal ini berarti konsep diri memberikan pengaruh sebesar 44,6\% terhadap entertainment-social. Kedua adalah hasil analisis untuk menguji 


\section{PSIKOVIDYA}

hubungan antara konsep diri dengan intense-personal yang dilakukan dengan

uji statistik korelasi product moment diperoleh koefisien korelasi (rxy) = $-0,625$ dengan taraf signifikansi $p=0,000$ ( $\mathrm{p}<0,01)$ yang berarti ada hubungan negatif yang sangat signifikan antara konsep diri dengan intense-personal. Apabila melihat dari uji regresi sederhana, sumbangan efektif konsep diri terhadap intense-personal sebesar 0,607 (r square).

Hal ini berarti konsep diri memberikan pengaruh sebesar $\quad 60,7 \quad \% \quad$ terhadap intense-personal. Ketiga adalah hasil analisis untuk menguji hubungan antara konsep diri dengan borderline pathological yang dilakukan dengan uji statistik korelasi product moment diperoleh koefisien korelasi (rxy) $=$ $-0,610$ dengan taraf signifikansi $p=0,000$ $(\mathrm{p}<0,01)$ yang berarti ada hubungan negatif yang sangat signifikan antara konsep diri dengan borderline pathological. Apabila melihat dari uji regresi sederhana, sumbangan efektif konsep diri terhadap borderline - pathological sebesar 0,372 (r square). Hal ini berarti bahwa konsep diri memberikan pengaruh sebesar $37,2 \%$ terhadap borderline - pathological. Keempat adalah hasil analisis untuk menguji perbedaan entertainment-social antara laki-laki dan perempuan yang dilakukan dengan uji T-test diperoleh nilai koefisien F sebesar 3,691 dengan taraf signifikansi $\mathrm{p}=0,634(\mathrm{p}>0,05)$ yang berarti tidak terdapat perbedaan entertainment-social antara laki-laki dan perempuan. Kelima adalah hasil analisis untuk menguji perbedaan intense-personal antara laki-laki dan perempuan yang dilakukan dengan uji mann-whitney diperoleh nilai koefisien $\mathrm{Z}$ sebesar $-0,959$ dengan taraf signifikansi $\mathrm{p}=0,338(\mathrm{p}>0,05)$ yang berarti tidak terdapat perbedaan intense-personal antara laki-laki dan perempuan. Keenam adalah Hasil analisis untuk menguji perbedaan borderline pathological antara laki-laki dan perempuan yang dilakukan uji mann-whitney diperoleh nilai koefisien $\mathrm{Z}$ sebesar $-1,097$ dengan taraf signifikansi $\mathrm{p}$ 


\section{PSIKOVIDYA}

Vol 22, No. 2, Desember 2018

$=0,273(\mathrm{p}>0,05)$ yang berarti tidak

diharapkan mengukur masing-masing

terdapat perbedaan borderline - aspek celebrity worship yakni

pathological antara laki-laki dan

entertainment-social, intense-personal,

perempuan.

dan borderline-pathological untuk

memperoleh hasil yang lebih spesifik.

\section{Kesimpulan dan Saran}

Penelitian selanjutnya juga diharapkan

Penelitian ini menunjukan bahwa

untuk berfokus pada subjek dewasa awal.

yang pertama ada hubungan negatif

antara konsep diri dengan celebrity

worship yang artinya semakin negatif

konsep diri maka semakin tinggi celebrity

worship, begitu juga sebaliknya, semakin

positif konsep diri maka semakin rendah

celebrity worship. Kedua, tidak terdapat

perbedaan celebrity worship antara

laki-laki dan perempuan, artinya dalam

memuja sosok selebriti idola, baik

laki-laki maupun perempuan menjadi

sama.

Keterbatasan dalam penelitian ini

adalah terkait dengan pengukuran

terhadap variabel tergantung yang diukur

sebagai suatu bentuk kesatuan dalam

celebrity worship, sehingga hasil yang

didapatkan adalah hasil secara umum dan

tidak spesifik. Penelitian selanjutnya

\section{Diskusi}

Penelitian ini membuktikan bahwa

terdapat hubungan negatif sangat signifikan antara konsep diri dengan celebrity worship. Celebrity worship adalah suatu perilaku dimana unsur utamanya adalah penyerapan psikologis terhadap sosok idola selebriti demi membangun sebuah identitas diri. Penyerapan psikologis berarti segala sesuatu yang terdapat dalam sosok idola tersebut diserap dan dimaknai oleh individu dalam hal ini remaja baik dari cara berpakaian, berbahasa, berbicara, dan berperilaku untuk menjadi tolak ukur dirinya sendiri. Penyerapan psikologi tersebut terjadi dalam tiga tahap atau proses yakni yang pertama adalah 
entertainment-social dimana remaja

merasa tertarik untuk terlibat dalam

kehidupan idola baik bakat, sikap, perilaku, bahkan kebiasaan idola dengan cara melakukan pencarian secara aktif melalui berbagai sosial media sampai pada mempelajari kehidupan idola.

Kegiatan ini tentu saja memberikan efek tertentu bagi setiap remaja sehingga tidak menutup kemungkinan berlanjut pada tahap kedua yaitu intense-personal dimana muncul semacam perasaan yang intens dan kompulsif dan mengarah ke perasaan obsesif dari remaja terhadap idolanya. Remaja merasakan ada keterikatan antara dirinya dengan idola bahkan muncul semacam sikap empati dalam diri remaja terhadap idolanya. Semakin dalam keterlibatan remaja pada kehidupan idola (celebrity involvement) mengakibatkan remaja bersikap tidak rasional atau pada tahap tiga disebut borderline-pathological. Remaja mulai berfantasi dan berkhayal tentang idolanya. Beberapa penelitian menyebutkan bahwa entertainment-social adalah tahap paling ringan, intense-personal adalah tahap sedang dan borderline-pahological adalah tahap esktrim. Media psikologi sering menyebut borderline-pathological sebagai bentuk "parasosial" yakni sebuah hubungan yang terbentuk antara fans dan idolanya (Giles \& Maltby, 2006). Dikatakan parasosial karena hubungan tersebut tidaklah nyata yang hanya terjadi di dunia maya.

"such individuals as possessing some magic 'charisma' that seduces the rest of us blindly into their slipstream”,-Giles \& Maltby, 2006

Giles dan Maltby (2006) dalam artikelnya hendak menjelaskan bahwa selebriti tertentu memiliki semacam kharisma yang membuat siapapun yang melihatnya seolah dibutakan. Kreativitas media dalam menciptakan dunia artificial bagi remaja dimana selebriti idolanya yang menjadi konten berpengaruh.

Dalam penelitian ini ditemukan bahwa ada hubungan yang negatif antara konsep diri dengan celebrity worship dengan koefisien korelasi -0,771 dan taraf 


\section{PSIKOVIDYA}

Vol 22, No. 2, Desember 2018

signifikansi $p=0,000(p<0,01)$. Hasil ini

dibuktikan dalam penelitian ini

menunjukan bahwa semakin negatif

mengatakan bahwa pada faktanya remaja

konsep diri maka semakin tinggi celebrity

pecinta budaya Korea di Manado

worship, begitu juga sebaliknya, semakin

memiliki konsep diri yang cenderung

positif konsep diri maka semakin rendah

negatif sehingga seperti apa yang

celebrity worship. Hal ini dikarenakan

dikatakan oleh Rice \& Dolgin (dalam

remaja yang memiliki konsep diri yang

Rahmaningsih \& Martani, 2014) selebriti

positif seharusnya mengenal dirinya

idola hallyu seolah menjadi orang yang

dengan baik, stabil, menerima kelebihan

penting baginya. Ketika remaja

dan kekurangan dirinya, tidak hanya

menganggap selebriti idola sebagai orang

menerima dirinya sendiri tetapi juga

yang penting baginya maka

orang lain apa adanya, dan memiliki

kecenderungan celebrity worship semakin

tujuan-tujuan yang realistis akan dirinya

tinggi. Apabila melakukan analisis regresi

sehingga meskipun idola pop korea hadir

sederhana dengan program spss ver. 20.0,

sebagai hasil dari interaksi budaya,

sumbangan efektif konsep diri terhadap

remaja tidak akan mudah terpengaruh.

celebrity worship, sebesar $0,594 \quad$ (r

Remaja dengan konsep diri yang positif

square). Hal ini berarti konsep diri

dalam proses belajar sosial melalui

memberikan pengaruh sebesar $59,4 \%$

modelling, masih melibatkan proses

terhadap celebrity worship. Hal ini sejalan

berpikir ketika memaknai informasi yang

dengan penelitian Gleason dkk (2017)

diterima (unsur-unsur dalam idola pop

mengatakan bahwa interaksi parasosial

korea) sehingga dapat memberikan

dan hubungan parasosial antara individu

penilaian seperti "apakah gaya koreanese

dengan idolanya berhubungan dengan

cocok untuk saya?" dan "apakah pembentukan identitas pada remaja dan

lingkungan saya dapat menerima gaya hubungan parasosial terjadi karena

koreanese ini". Sedangkan apa yang telah konsep diri yang negatif dalam diri 
remaja.

Dalam penelitian ini juga ditemukan bahwa tidak ada perbedaan yang berarti celebrity worship pada laki-laki dan perempuan dengan nilai $\mathrm{Z}=$ $-0,157$ pada taraf signifikansi sebesar 0,876 ( $\mathrm{p}>0,05)$. Hasil ini menunjukan bahwa ketika memuja seorang selebriti idola dalam hal ini idola pop korea, baik laki-laki maupun perempuan tidak terdapat perbedaan. Apabila melihat mean, laki-laki berada pada 42,08 dan perempuan pada 42,92. Hal ini berarti, terdapat perbedaan namun tidak berarti. Namun demikian berdasarkan hasil observasi dan wawancara yang dilakukan peneliti selama proses pengambilan data, hal yang nampak adalah perbedaan dalam cara mengekspresikan kecintaan terhadap selebriti idola antara laki-laki dan perempuan. Baik pada saat pengisian skala maupun wawancara, remaja perempuan cenderung lebih ekspresif dengan berkata seperti "wah! Ini benar-benar menggambarkan apa yang saya rasakan" atau "kenapa ini sesuai dengan apa yang saya lakukan?” atau berekspresi dengan menjerit senang, heran, tertawa, sedangkan remaja laki-laki cenderung berpikir panjang ketika hendak mengisi angket. Ketika ditanyakan tentang rasa suka terhadap idola, remaja laki-laki cenderung malu dan tidak ingin terlalu frontal dalam menunjukan kecintaannya seperti remaja perempuan.

\section{Referensi}

Bandura, A. (1967). The role of modeling processes in personality development. In W. Hartup \& N. Smothergill (Eds.), The young child. Washington: National Association for the Education of Young Children.

Burns, R. B., (1993). Konsep Diri : Teori, Pengukuran, Perkembangan, dan Perilaku. Jakarta : Arcan

Calhoun, J. F., Acocella, J. R., (1990). Psikologi tentang Penyesuaian dan Hubungan Kemanusiaan. (Ahli bahasa : Satmoko). Semarang : IKIP Semarang Press.

Darfiyanti, D., Putra. (2012). Pemujaan terhadap Idola sebagai Dasar Intimate Relationship pada Dewasa Awal : Sebuah Studi Kasus. Jurnal Psikologi Kepibadian \& Sosial, 1(2), 53-60

Falah, N. (2004). Aplikasi Teori Modelling dalam Pembinaan Shalat pada Anak. Jurnal Aplikasi Ilmu-Ilmu Agama, 5(1), 47-59

Hennida. C., Felayati, R. A., Wijayanto, S H., \& Perdana, A. R., 2010. Budaya dan Pembangunan Ekonomi di Jepang, Korea Selatan, dan China. Jurnal Global \& Strategis, 10(2), 248-263) 
Jae, J. S., Lee, S. H., \& Lee, S. G. 2017. When Indonesians Routinely Consume Korean Pop Culture : Revisiting Jakartan Fans of The Korean Drama Dae Jang Geum. International Journal of Communication 11, 2288-2307

Jannah, M. (2014). Gambaran Identitas Diri Remaja Akhir Wanita yang Memiliki Fanatisme K-Pop di Samarinda. E-Jurnal Psikologi, 2(2), 182-194

KCIS. 2011. The Korean Wave : A New Pop Culture Phenomenon. Korea : The Korean Culture and Information Centre

Kurniati, A., Indiati., \& Yuhenita, N. N. (2015)., Dampa Demam Virus Korea Terhadap Identitas Diri Remaja. Jurnal Transformasi, 11(1), 54-59

Lee, S. J. 2011. The Korean Wave : The Seoul of Asia. The Elon Journal of Undergraduate Research in Communications, 2(1), 85-93

Maltby, J., dkk (2006). Extreme Celebrity Worship, Fantasi Proneness and Dissociation : Developing The Measurement and Understanding of Celebrity Worship Within A Clinical Personality Context. Journal of Personality and Individual Differences 40, 273-283

Piscarac, D. 2016. Medical K-Dramas : A Cross-Section of South Korea's Global Culture Industry. Journal of Sociological Studies 1, 43-60

Pramita, Y., Harto, S. 2016. Pengaruh Hallyu Terhadap Minat Masyarakat Indonesia untuk Berwisata ke Korea Selatan. Jurnal Online Mahasiswa Fakultas Ilmu Sosial dan Ilmu Politik, 3(2), 1-15

Rahmaningsih, N. D., Martani, W. (2014). Dinamika Konsep Diri pada Remaja Perempuan Pembaca Teenlit. Jurnal Psikologi UGM, 41(2), 179-189

Sunarni. 2015. Pengaruh Celebrity Worship terhadap Identitas Diri Remaja Usia SMA di Kota Yogyakarta. Jurnal Riset
Mahasiswa Bimbingan dan

Konseling, 5(1), 1-8

Suryani, N. P. E., (2014). Korean Wave Sebagai Instrumen Soft Power untuk Memperoleh Keuntungan Ekonomi Korea Selatan. Jurnal Global, 16(1), 69-83

Santrock, J. W. (2007). Psikologi Pendidikan (Edisi Kedua). (Penerj. Tri Wibowo B. S). Jakarta : Kencana

Syam, H. M. (2015). Globalisasi Media dan Penyerapan Budaya Asing : Analisis pada Pengaruh Budaya Populer Korea Di Kalangan Remaja Kota Banda Aceh. Jurnal Ilmu Komunikasi, 3(1), 54-70

Widjaja, A. K., Ali, M. M. 2015. Gambaran Celebrity Worship pada Dewasa Awal di Jakarta. Humaniora Journal, 6(1), 21-28

Tempo. (2016, Oktober 26). Hallyu Wave, Kunci Popularitas Fashion Korea Selatan. Diakses pada 18 Juni 2017 dari

https://cantik.tempo.co/read/815206/hally u-wave-kunci-popularitas-fashionkorea-selatan

Wikipedia (2016). Hallyu. Diakses pada 18 Juni 2017 dari https://id.wikipedia.org/wiki/Hallyu 